\title{
Margaret Ridley Charlton, Medical Librarian and Historian: An Evaluation of her Career
}

\author{
by Frances Groen
}

Margaret Charlton, Assistant Librarian of the McGill Medical Library from 1895 to 1914, played a leading role in the formation of the Medical Library Association, of which she became the first Secretary. Her career at McGill's Medical Library appears to have been a colourful one and brought ber into contact with many of the faculty. After leaving Mc Gill in 1914, she was appointed as Librarian at the Academy of Medicine in Toronto where she devoted herself to ber lifelong interest in the history of medicine. Her contribution to bistorical medical scholarship in Quebec is evaluated.

Margaret Charlton, bibliothécaire adjointe de la bibliothèque de médecine de McGill de 1895 à 1914, a joué un rôle capital dans la création de l'Association des bibliothèques de médecine dont elle fut la première secrétaire. Sa carrière à la bibliothèque de médecine de McGill semble avoir été baute en couleurs et lui a permis de faire la connaissance de nombreux professeurs. Elle a quitté McGill en 1914 pour un poste de bibliothécaire à l'Académie de médecine de Toronto où elle s'est entièrement consacrée à sa passion de toujours, l'bistoire de la médecine. Une évaluation de sa contribution aux études de l'bistoire de la médecine au Québec est présentée.

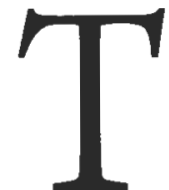

he Anniversary Medal of the Medical Library Association, struck in 1976 to a firm, even severe expression combined with the refinement characteristic of a lady of the era. commemorate the Association's 75th Her hair is drawn back high off her forehead and people credited with the founding of the Association in 1898 . On the right is the familiar, heavily moustached face of Sir William Osler, on the left, the bearded Dr. George Milbray Gould. At centre, flanked by these eminent physicians, is a threequarter profile of Miss Margaret Charlton, one time Assistant Medical Librarian of McGill University. Margaret Charlton (1858-1931) was forty years of age at the time that the Association was founded. Her face shows

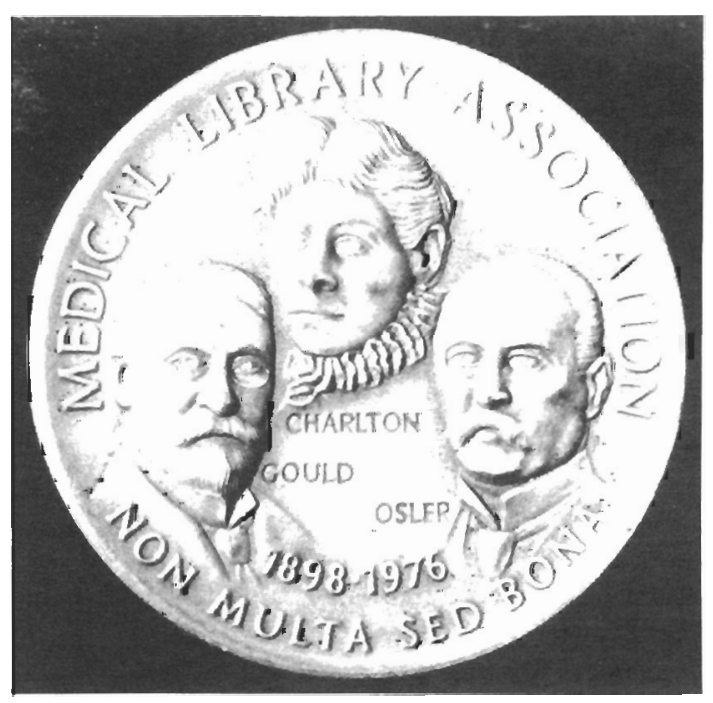

Commemorative Medal of the Medical Library Association are framed by a high Victorian collar. In sum, she appears to be very much a lady of her time.

In 1895, in her thirtyseventh year, Margaret Charlton was engaged by the Faculty of Medicine of McGill University to work in the Faculty Library. When she came to the Library, it was already 72 years old and the largest in North America connected with a medical school. At the time, it contained 14,000 volumes, and during her 19 year tenure, 10,000 volumes were added. Margaret Charlton 


\section{Margaret Ridley Charlton}

entered the profession of librarianship following a career in literary journalism in which she wrote numerous historical sketches for the Dominion Illustrated Monthly and several books.' In entering librarianship she was ahead of her time, for at the end of the last century, in Canada at least, librarianship as a profession for women had not developed to any extent. By the standards of genteel ladies of her day, she was well educated for the position, having attended the Montreal High School and a summer course in librarianship at Amherst College in Amherst, Massachusetts, where Melvil Dewey taught. In his presidential address to the Medical Library Association in $1936,{ }^{2} \mathrm{Dr}$. W. W. Francis, the first Osler Librarian, describes her as "thoroughly imbued, perhaps...be-Dewied with his classification."

Miss Charlton remained as Assistant Medical Librarian at McGill until 1914, when she resigned to take charge of the Academy of Medicine Library, Toronto. We do not know the precise conditions of Margaret Charlton's initial appointment at McGill in 1895. However, by 1896 she was already interested in library work beyond her immediate place of employment, for the Minutes of the Library Committee of the Faculty of Medicine record a re-imbursement of $\$ 55$ to Miss Charlton for her expenses in attending a meeting of the American Library Association in Chicago. ${ }^{3}$

Medical education was cleveloping rapidly throughout North America and the need for well managed medical libraries in support of medical education was increasingly evident to medical educators. In I 898, Dr. George M. Gould invited a group of physicians and librarians to a meeting in his editorial office of the Pbiladelphia Medical Journal to launch a new Association for medical librarians. Margaret Charlton was one of those invited to attend. Martha Noyes, another early pioneer in medical libraries, gives credit to Margaret Charlton for founding the Association and attributes Charton's commitment, in part, to her frustration when she attempted to find solutions to medical library problems within the American Library Association. Miss Noyes writes of Margaret Charlton as follows:

Miss Charlton was the one person who indirectly brought the Association into being from speaking with Dr. Osler. She had belonged to the American Library Association. Their problems were not our problems, and she felt lost and that the time was wasted, yet she had striven for contact with those doing just the sort of work she was doing. And so she suggested to Dr. Osler that it would be a fine thing if the Medical Librarians could do the same sort of thing the American Library Association was doing. ${ }^{4}$

Margaret Charlton welcomed the challenge of helping in the founding of the Medical Library Association and embraced these heavy responsibilities with enthusiasm. ${ }^{5}$ Writing to William Browning, MD, Librarian of the Medical Society, County of Kings, New York, on March 31, 1895, she invited him to attend the meeting in Dr. Gould's editorial offices on May 9, 1898 ,

It is proposed to form a Medical Librarian's Association whereby the vast medical literature all over the world may be utilized. Dr. Gould has commissioned me to do all the correspondence relating to the formation of the Medical Librarians' Association as he himself has not the time at present to devote to it.

She continued to devote herself to this association and wrote again in May, 1898 to Dr. Browning, "The more 1 think of our Association, the more I hope it will prove a success and that next year when we meet, it will be with the feeling that we have done our best to make it the success it deserves to be." Her dedication was sustained, but with a realism, portrayed in correspondence with Dr. Browning on Junc 27 , 1898, "Our Library Movement scems to be growing only I think that ... they are going a little too fast. To have a library in every village cloes not seem necessary."

In these early letters, Margaret Charlton also displayed her concern with some of the continuing themes in medical library practice. She was concerned that adequate collections of medical journals be established, and to this purpose wrote to publishers and medical societies to join the new Association and to ask them to furnish their journals or transactions free 


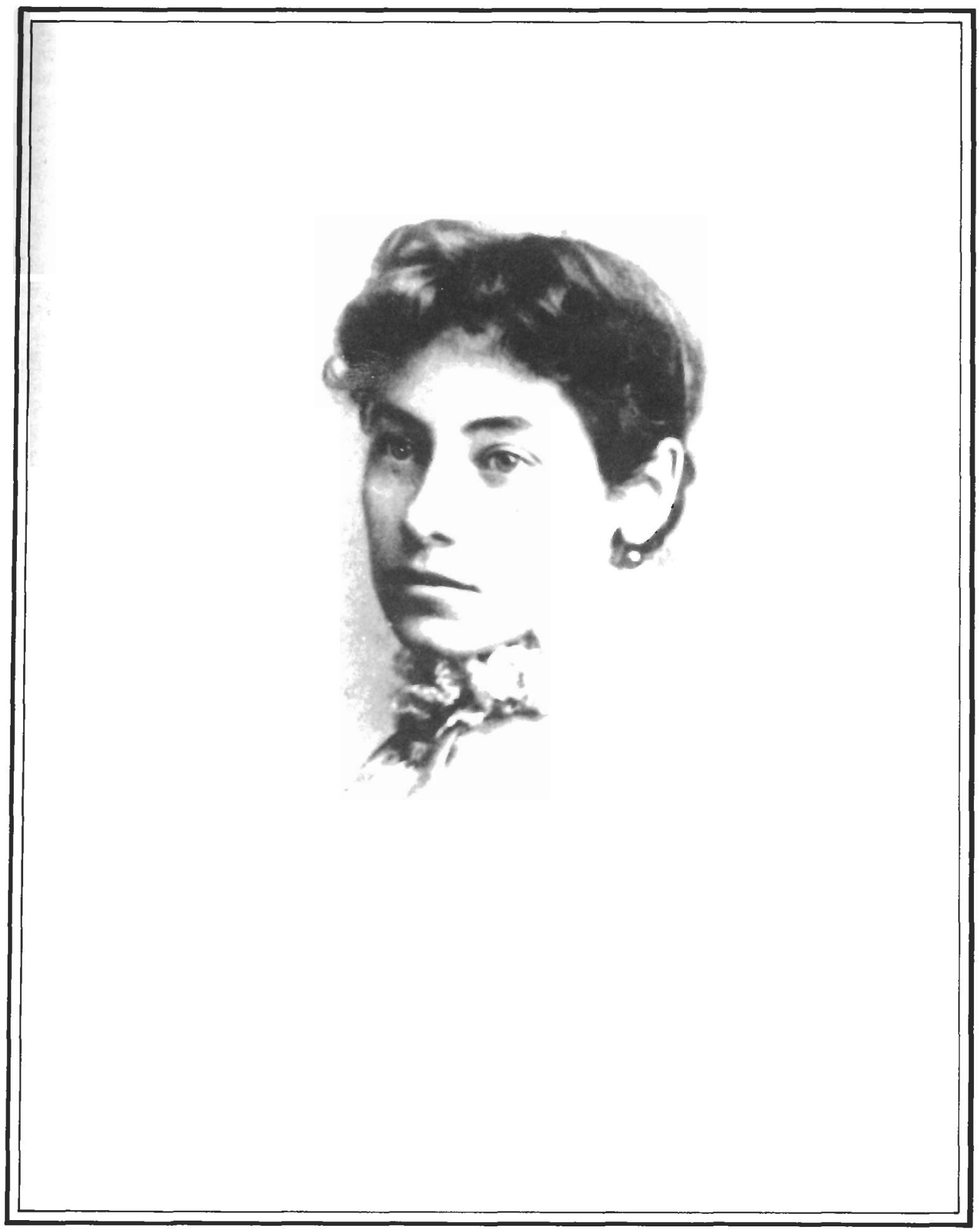

Margaret Ridley Charlton, ca. 1895. Osler Library. 


\section{Margaret Ridley Charlton}

to libraries joining the Association. On the importance of separate medical libraries she wrote to Dr. Browning on July 25, 1898, "I am very much opposed to his [Dr. George M. Gould] idea of medical libraries in public libraries and strongly maintain that medical libraries should be housed by themselves." She struck a subservient note on this issue, however, when she commented, "Of course if you ... agree with Dr. Gould, 1 shall say no more about it." She was delighted to hear subsequently that Dr. Browning supported her stand, "I have read your paper which appeared in the Pbiladelpbia Weekly and I am delighted with it. I agree with you in reference to the libraries being apart from general libraries wherever practicable."

One year later, the fledgling Association had gotten off the ground, and Margaret Charlton noted that she had written to all members of the Association to ask them when they would like to hold a meeting. The question of fees for membership arose, and she wrote to Dr. Browning in his capacity as Treasurer of the Association of Medical Librarians. "I am sorry that we have to ask the medical libraries for $\$ 25$ as most of them are too poor to subscribe." Dr. Browning was a frequent recipient of letters from Miss Charlton on all matters relating to the new Association. With the first annual meeting scheduled for the autumn of 1899, Margaret Charlton was beginning to feel some pressure, revealed in her comment in a letter of October 16, 1899 to Dr. Browning. "How stupid of me to send that check ... without endorsing it and kind of you not to say 'Just like a woman.' "'

Having been instrumental in the founding of an association for medical librarians, Margaret Charlton became its first secretary in 1898 and continued in that role until 1903 , returning again as secretary from 1909 until 1911. As an historical aside, it is interesting to note that the Medical Library Association was not presided over by a woman until 1933. From its beginning until that year, the Association's presidents had been prominent physicians interested in medical libraries. In 1933, librarian Marcia C. Noyes was elected president thus breaking this tradition of physician presidents.

The tradition of physicians as Presidents of the Medical Library Association was also characteristic of appointments of physicians as directors of medical school libraries. Within the
Faculty of Medicine at McGill University, the history of distinguished physicians as chief librarians began with Dr. Andrew Fernando Holmes, one of the four founders of the Faculty of Medicine. Holmes was in charge of the Library of the Montreal Medical Institute which was founded in 1823. This became the McGill Medical Faculty in 1829, and Holmes continued in charge of its Medical Library until his death in 1860. Sir William Osler also acted informally during his years at McGill as volunteer librarian for the medical school although he was not officially appointed to this role. It is not difficult to imagine Osler in this role, volunteer or otherwise, For nineteen years, Margaret Charlton was Assistant Medical Librarian to the Honorary Medical Librarian, Dr. Frederick Gault Finley, who held this post from 1895 until 1914 . As practicing Assistant Medical Librarian, Margaret Charlton must have enjoyed the support and encouragement of Dr. Finley whose term as Honorary Librarian overlapped so closely with her own period at McGill.

All was not harmony within the Library, however; Dr. William Francis, Osler Librarian, noted in his 1936 Presidential Address to the Medical library Association that:

.. a sensitive, book-devouring
investigator was disliked by and
positively afraid of our mild librarian!
For though there was always a quiet
dignity about Miss Charlton, it did not
conceal her fervid likes and dislikes.

There was, however, more at stake than the personal preferences of Miss Charlton. In 1908, the Minutes of the Library Committee of the Faculty of Medicine of McGill University stated that

The assistant librarian's attention should be drawn to the laxity with which journals are taken out by members of the staff and not recorded .... that, moreover, it is essential that civility be shown to all who decide to make use of the Library. ${ }^{7.8}$

By 1912, the dissatisfaction with Margaret Charlton's managment appears to have reached a crescendo. The Library Committee Minutes again express the concerns as follows:

... the cataloguing was very far behind and ... was not keeping pace with the 


\section{Margaret Ridley Charlton}

accessions. As to the bookkeeping, there were serious complaints that this was badly muddled. There was more than a suspicion that accounts had been not infrequently twice paid. ${ }^{9}$

By this time the staff of the Library, in addition to Miss Charlton, consisted of two full time assistants and a third half-time. The Committee recommended that the two full time assistants be dismissed and replaced by a second Assistant Librarian, equal in status to Miss Charlton who would be in charge of correspondence, the lending library and the reading room. By the end of 1914, Margaret Charlton had left the McGill Medical Library. Years later, in 1936, Dr. Finley who had been honorary librarian, wrote in a letter to Dr. Francis:

\section{1 held on to the post of Hon. Librarian long after I should have resigned as I knew that few others would have tolerated her (Miss Charlton's) vagaries, which in my opinion were more than balanced by her energies and ability. ${ }^{10}$}

The career of Margaret Charlton in the Faculty of Medicine of McGill University is particularly touching, and her story is one that deserves much study. She resembles other outspoken Canadian women of her period, the novelist Sarah Jeanette Duncan, the poet Pauline Johnson, and others whose colourful and dominant personalities were masked by a combination of Victorian standards and behavioural conventions. Although recognized for their work, they were frequently viewed askance by their contemporaries.

Certain aspects of Margaret Charlton's career demonstrate her successful efforts to integrate the needs of her library's users at a local level with developments in the medical library world. She reported in 1902 to the Library Committee that:

Those engaged in research in the Library have been greatly inconvenienced by the discontinuance of the Index Medicus. The Index published in Paris has been found a very unsatisfactory substitute, and it seems likely to be discontinued. The Association of Medical librarians is trying to see what can be done to start it again. I submit for your inspection the first number of the Bulletin of the Association of Medical Librarians. "

This q:ıtation illustrates Margaret Chartlon at her professional best. Her concern with adequate tools for retrieving the medical literature is clearly expressed in her dissatisfaction with the short-lived French publication, Bibliographie Médicale, and her efforts to improve this situation are evident. We also see her as someone not only in touch with her times but willing to do something to improve them. Her presentation to the Library Committee of the first volume of the Bulletin, which continues today as the world's leading publication in the field of medical librarianship, must have given her considerable pride and a feeling of accomplishment. Margaret Charlton was indeed fully "au courant" and well integrated into her profession. She was also well motivated on behalf of users

Although Margaret Charlton's career demonstrates several essential attributes of the successful librarian, we have seen that her professional life was not entirely successful. She had entered the field of medical librarianship when it was in its infancy. She appears to have lacked the management, technical and human skills necessary in the medical librarian of today. But in her defense, it is necessary to reemphasize that her profession was still being defined: the first course in medical bibliography taught by librarians was not offered until 1937 , nor was there a professional librarian at the U.S. National Library of Medicine until 1942.

In her career, Margaret Charlton was fortunate to have been associated with two institutions that enjoyed significant library resources and played a significant role in the development of the medical profession in Canada. In the case of both the Faculty of Medicine Library of McGill University and the Library of the Academy of Medicine in Toronto, historical collections were significant and enriched her studies in the history of medicine. It should be recalled that during Charlton's tenure as Assistant Medical Librarian at McGill University, both current and historic medical collections were subsumed in one collection in the Medical Library. It was in 1929 with the arrival of the bequest of Sir William Osler's 


\section{Margaret Ridley Charlton}

historical collection at McGill University that a history of medicine library came into existence. It was later to be enhanced by extensive transfers of rare and valuable historical materials from the stacks of the Medical Library, as McGill librarians became aware of the value of these early medical books and the need to protect them.

The circumstances under which Miss Charlton left McGill University appear to have been far from amicable. In Dr. Francis' 1936 Presidential Address to the Medical Library Association, he speaks compassionately of her departure from her beloved library:

To lose a job to which one has devoted head, heart, hand and twenty of one's best years must be one of the major tragedies of life. Each of us is his own worst enemy, and if Miss Charlton was a hero-worshipper, her aversions were equally strong and not always so reasonable. Her principles, I think, were uncompromisingly rigid. For years she had worked under a chief, the Honorary Librarian, a member of the Faculty, one who is an extraordinary angelic combination of wisdom, courtesy, patience and good humor. In other words, she had been largely her own master. In 1913, he was succeeded by a new broom which raised a lot of dust. After a year of intolerable friction the new chief drew up a program which she could not, or would not, carry out. The irresistible force met an immovable spirit in a not unremovable body and in May, 1914, she resigned. A bitter sense of injustice prevented her ever revisiting her old haunts, and 15 years later I could not induce her to come, openly or surreptitiously, to see the newly arrived Osler Library which would have interested her intensely. ${ }^{12}$

A review of the subsequent publications of Margaret Charlton verifies Dr. Francis' observation that the Osler Library would indeed have interested her intensely. She was yet to produce her most substantial historical writing, a series of articles on the history of medicine in Lower Canada, published in four parts in the Annals of Medical History between 1923 and $1924 .{ }^{13}$ In this series, beginning with medicine in Quebec during the French regime, 1608-1759, Miss Charlton draws on her knowledge of Quebec and her ability to use historical resources effectively. These articles appeared almost a decade after Margaret Charlton left Montreal for her position as Librarian of the Academy of Medicine. Yet, obviously, her mind remained much occupied with Quebec during her tenure at the Academy. One suspects that Margaret Charlton's spiritual home remained McGill and the Montreal medical community.

The Annals of Medical History articles draw on Margaret Charlton's knowledge of Quebec history and the history of medicine. In the first article of this series, on the coming of the first physicians to Canada and Louis Hébert, her account is factual and somewhat pedantic:

Every student of Canadian history knows that from the first days of the colonization of New France, an important role as colonists was played by members of the medical profession. ${ }^{14}$

Her account of the early colonization of Quebec is detailed with important facts and dates, although the contemporary historian may wish that she had documented her sources more thoroughly in the interests of those who tread her footsteps over sixty years later. Her account of the terrible havoc and ruin which the Iroquois were to bring upon the French settlements shows her conceptual framework as thoroughly indoctrinated with a conventional attitude towards the Indian wars.

But Margaret Charlton's account of Jeanne Mance and her resolve to minister to the sick and suffering of Quebec is both warm and compassionate. This detailed review of the contribution of Jeanne Mance to medical care in New France tempts the student of Margaret Charlton's life to wonder how closely she might have identified with this devoted "religieuse." She refers to Jeanne Mance's virtues, "the rare qualities of courage, zeal, tact, and an unfailing sympathy and tenderness of heart." 15 Despite the gulf of time that separated these two women, the distance between them narrows in reading Margaret Charlton's remarks on Jeanne Mance. Like Miss Charlton who was injured in a strange, painful accident when a heavy electric globe fell on her head during a train voyage from Toronto to Montreal, ${ }^{16}$ Mlle Mance 


\section{Margaret Ridley Charlton}

experienced an accident when she fell on the ice and broke her right forearm and dislocated the wrist. The fractures were treated, but the dislocation was not discovered until it was too late to cure. Jeanne Mance suffered much from this injury and was prevented from ever resuming her active work in the hospital. Margaret Charlton also suffered greatly from her accident until her death on May 31, 1931 at the age of 72 , nine years after the accident occurred.

In the second and third articles in her Annals of Medical History series, M. Charlton, as she is identified in these articles, reviews early epidemics in Lower Canada, detailing the progress of St. Paul's Disease in Quebec, which was described in the literature of the period as "nothing more than a confirmed syphilis showing itself in different ways in different parts of the body and making anomalous symptoms and appearances accordingly. The habits of Canadians facilitate its communication in various ways." 17 The epidemic of the Molbay Disease, eponymiously named after its first discovery in the Parish of Molbay below Quebec, is also described in part two in great detail, quoting extensively from the literature of the period. These full text reproductions of the carly writings on contagion provide valuable historical documentation for contemporary historians of disease who lack access to the original source documents.

In the third article, Margaret Charlton continues her examination of disease in Quebec after the victory of General Wolfe. She branches into issues of early medical licensure in Quebec and the growth of medical practice. These articles provide a wealth of fascinating factual information: "In 1806, Dr. Blanchet, with four other French Canadians, founded in Quebec the first French newspaper in Canada. It was named Le Canadien, and had as its motto "Nos institutions, notre langue, et nos lois." 18 Similarly, we learn that "the earliest inoculation in Canada was performed at Quebec in the year 1768 by a Mr. Latham, surgeon to the King's (or Eighth) Regiment of Foot." 19 This article, like its predecessor, is characterized by heavy reliance on primary source documents, some of which are reproduced in their entirety. It is evident that the author used fully all historical resources available to her.

In the fourth and final of the Annals articles, referred to as her "magnum opus" by Dr. Francis, Margaret Charlton returns to the Faculty of Medicine of McGill University. Despite her refusal to return to McGill, she demonstrates in this article that, in spirit, she never left the University. She shows herself to be a Canadian nationalist as well, when she writes "It was not until the beginning of the nineteenth century that those wishing to pursue the study of medicine could do so in their own country.",20 This fourth article in the series provides historians with an excellent summary of the development of medical education in Montreal. Margaret Charlton describes education for medicine prior to the foundation of medical schools in the province and the early days of medical education in Quebec. Quoting from the work of Professor Francis J. Shepherd, ${ }^{21}$ she elaborates on the difficulties involved in obtaining subjects for dissection and on the practice of body-snatching and reviews the work of early Quebec medical luminaries. She appears to have been especially interested in the treatment of the insane in Quebec and in improvements brought about in the midnineteenth century by Dr. James Douglas.

Of particular interest to librarians and medical history scholars is Miss Charlton's review of the development of the medical journalism in Canada. Not surprisingly, the reader learns that the first medical journal in Canada, Le Journal de Médecine de Québec, was published in both French and English in Quebec in 1826. Simultaneous with this short-lived journal was the establishment of the Quebec Medical Society. Later in the same article, the author returns to the subject of early Canadian medical publishing. She notes the appearance of the first English language medical journal in 1844 , the Montreal Medical Gazette, under the editorship of Dr. Francis Badgley and Dr. William Sutherland, equally short-lived, lasting only from April 1844 to April 1845. Shortly thereafter, another journal, the British-American Medical and Pbysical Journal appeared. It was largely the work of members of McGill University faculty.

Margaret Charlton also considers in this article the beginning of the collecting of morbidity and mortality statistics in Lower Canada. She notes that, "by 1839 Montreal had one of the best water supplies of any city on the continent. Some of these pipes have been lately presented 
to the Hygiene Museum of McGill University, They were dug up during the widening of St. Antoine Street."22 Public hygiene and the development of a growing immigrant population, largely English speaking, promoted the development of health care facilities, and she documents the work of the Montreal Emigrant Society and the Female Benevolent Society which led to the development of "The House of Recovery," to become, in 1819, the Montreal General Hospital. She draws upon the resources of the McGill Medical Library in documenting the early history of this hospital. Again, her nationalism, both general and local, rises to the fore as she notes, "Canadians cannot but feel proud when they realize how much had been accomplished in less than a century .... The first four physicians in the Montreal General Hospital and the Medical Institution must ever be accounted by Canadians as men who filled a high position with great ability. As Dr. Howard remarked: 'Too much stress cannot be given to the fact that the existence of McGill University is largely due to these men',',23

Margaret Charlton describes the developments that led to the foundation of McGill University and the Faculty of Medicine, whose histories are indelibly entwined. The creation of a university from a flourishing medical school, The Montreal Medical Institution, has been fully described and carefully documented elsewhere. ${ }^{24}$ Miss Charlton's prose captures the flavour of this development as well as her glowing views of this event:

The founders of the school gave up its identity to save the charter of that [McGill] University, and it is interesting to note that the university originally owed its existence to the medical man: Dr. Stephenson, when others were indifferent, worked with such energy that he secured the bequest of James McGill for a college, when his will was being successfully contested by his heirs. ${ }^{25}$

Margaret Charlton's articles in the Annals of Medical History tell us much about the history of medicine in Qucbec. Her approach to her vast subject is chronological, and she branches off at frequent intervals. She does not always document her historical references thoroughly, and she frequently returns to a subject, as in the case of early medical publishing, with the result that her story is at times fragmented. Nonetheless, these articles are a historical treasure, and the reader today senses that she poured her heart as well as her mind into their writing. They are truly her farewell to a profession and a University that she continued to love long after she had left it.

\section{Notes}

The author wishes to thank Dr. E. H. Bensley, Honorary Osler Librarian, for his careful reading and corrections to the manuscript. Any remaining errors are the author's responsibility. Thanks are also due to Dr. Faith Wallis, Osler Library, and Phebe Chartrand, McGill University Archives, for their generous assistance.

1. Margaret Charlton collaborated with Miss C. A. Fraser in writing several books: $A$ Wonder Web of Stories (1892) and With Printless Foot (1894). The former is a two volume collection of fairy tales, the first such collection to be published in Canada. She is cited in Canadian Men and Women of the Time (1898) and in R. E. Watters: Checklist of Canadian Literature, 1629-1960. 2nd ed: (1972) Toronto, University of Toronto Press. The help of Marc Richard, Reference Librarian, McLennan Library, in locating these references is gratefully acknowledged.

2. W.W. Francis, "The President's Address: Margaret Charlton and the Early Days of the Medical Library Association." Bulletin of the Medical Library Association, 25 (1936): 61.

3. Martha Benjamin, "The McGill Medical Library, I829-1929;" (a thesis submitted to the Faculty of Graduate Studies and Research in partial fulfillment of the requirements for the degree of Master of Library Science, Montreal, 1960), p. 93.

4. Martha Noyes, Tuesday Evening Meeting. (Recorded comments). Bulletin of the Medical Library Association, 23 (1934): 33.

5. The history of the founding of the Association of Medical Librarians, later the Medical Library Association, is contained in the papers of the Medical Library Association housed 
in the Archives of the National Library of Medicine, Bethesda, Md. Permission to quote from these letters is given by the Executive Director of the Medical Library Association. The author acknowledges with gratitude the assistance of $\mathrm{Mr}$. Peter B. Hirtle, Curator, Modern Manuscripts, History of Medicine Division, National Library of Medicine. Information and quotations are drawn from the letters of Miss Charlton in this collection dated March 31, 1898; May 6, 1898; June 27, 1898; July 18,1898 ; July 25,1898 ; February 10,1899 ; February 20, 1899; May 27, 1899; July 14, 1899; September 6, 1899; September 19, 1899; October 16, 1899; October 23, 1899; March 22, 1900.

6. W.W. Francis: 62 .

7. The correspondence and other administrative materials related to the history of the Medical Library of McGill University are housed in the Archives of the Osler Library. The Librarian's Reports and Minutes of Meetings of the Library Committee are contained in this collection. In 1988 the name of the Medical Library was changed to the Health Sciences Library.

8. McGill University, Faculty of Medicine. Library Committee. Minutes of Meeting held February 26, 1908.

9. McGill University, Faculty of Medicine. Library Committee. Minutes of the Meeting held November 29, 1912.

10. Letter from Dr. Finley to Dr. W. W Francis, dated November 8, 1936 and quoted in Benjamin: 95.

11. McGill University, Faculty of Medicine. Report of the Assistant Librarian to the Library Committee, 1902.

12. W.W. Francis: 61 .

13. M. Charlton. "Outlines of the History of Medicine in Lower Canada under the French Regime, 1608-1759" Annals of Medical History, 5 (1923): 150-174.

"Outlines of the History of Medicine in Lower Canada. Continued." Annals of Medical History, 5 (1923): 263-278.

"Outlines of the History of Medicine in Lower Canada under the English Regime." Annals of Medical History, 6 (1924): 222-235. in Lower Canada. Conclusion." Annals of Medical History, 6 (1924): 312-354.

Miss Charlton also contributed to Canadian medical history outside Quebec through her article on Christopher Widner (1780-1858), a veteran of the War of 1812 and the first qualified physician in York. Annals of Medical History, 4 (1922): 346-350. For a short commentary on the Annals articles, see Sylvio Leblond, "Margaret Charlton: notice biographique." Canadian Society for the History of Medicine Newsletter (Spring, 1983): 15-16.1 am grateful to Dr. Carole Gerson, Vancouver, who is compiling a biographical dictionary on some 400 Canadian women who published fiction in Canada prior to 1940 for drawing this article to my attention.

14. Charlton. Annals. 5: 151.

15. 5: 159 .

16. W.W. Francis: 62 .

17. Letter written by Dr. Charles Black, surgeon, and quoted by Charlton. Annals, 5: 266.

18. Annals. 6: 266.

19. Annals. 6: 233.

20. Annals. 6: 312 .

21. Francis J. Shepherd, Reminiscences of Student Days and the Dissection Room. (MontreaI: 1919). Privately printed.

22. Annals. 6: 323.

23. Annals. 6: 327 .

24. Edward A. Bensley, "The beginnings of teaching at McGill University." McGill Journal of Education (1971) 6. 1: 1-2.

25. Annals. 6: 333. 